\title{
RELATIONS BETWEEN ECONOMIC GROWTH AND DECENTRALIZATION
}

\author{
N. Markov* \\ Faculty of Economics, Trakia University, Stara Zagora, Bulgaria
}

\begin{abstract}
The scientific literature attempts to seek the effects of certain public - political processes on economic growth. The goal of this study is to analyze some possible relations between economic growth and the decentralization. The results that are derived indicate that it is possible to discover some relations between economic and public processes. The conclusions give reasons to believe that economic growth can be influenced from the politics in the area of local self-government.
\end{abstract}

Key words: Economic growth, Decentralization, Relations, Impact, Self-government

\section{INTRODUCTION}

In 1996, in their study, Davoodi and Zou present a research indicating two correlations. The first correlation describes the negative relation between financial decentralization and economic growth in the developing countries. The second correlation explains the positive relation between financial decentralization and economic growth in the developed countries. The authors of this study, Davoodi and Zou, propose several explanations for the negative correlation such as deterioration in the public costs of the local levels of government /preponderance of current remuneration costs and etc. over the capital costs/, incorrect distribution of revenue authorizations, limitation of authorizations of central government, as well as insufficient knowledge of local tastes and preferences.

In 1999, as part of their research Xie, Zou and Davoodi, made a new test of the relations between decentralization and economic growth but this time only for US using authentic dynamic time lines for different time periods of the economic history. The methods used are similar to the previous research. Of all calculations done, the authors conclude that the American economy and administrative government body have reached their maximum level of decentralization. Authors also believe that the further development of

\footnotetext{
* Correspondence to: Nedelin Markov, Stara Zagora, Student campus, Trakia University, Faculty of economics, 6000, +35942699436 email: n_markov@uni-sz.bg
}

decentralization processes and transfer of more authorities to the subnational levels of public government shall lead to negative influence over the American economy.

A year earlier /1998/, Zhang and Zou reach the same conclusion. They surprisingly discovered that after the administrative reforms in 1970, China started to demonstrate more of an inverse relation between the fiscal decentralization and economic growth in certain Chinese provinces.

When analyzing data covering more recent time period, it is possible to find a positive relation between decentralization and economic growth. This conclusion was made by Atushi Iimi. The object of his analysis included 51 countries and was based on data for a 5 - year period starting from 1997 to 2001. Referring to already approved econometric models from similar researches, he found a positive influence over the decentralization /measured as a portion of the local costs from all public costs/ over the economic growth per capita of the population.

In another research made in 2009, Andres Rodriguez-Pose and Anne Kroijer examine again the relation between fiscal decentralization and economic growth this time in the countries of the Central and Eastern Europe. Data used covered the period from 1990 - 2004. The innovative approach of this research lies in the fact that the decentralization is reviewed in two different cross-sections - decentralization of already accumulated resources and decentralization of 
the authorizations for accumulating of resources. The results from this research are intriguing. There is a negative relation between the decentralization and economic growth with regard to the portion of costs on local level and transfers from central to local administration. However, the transfer of taxes shows positive influence over the economic growth for a certain period of time.

Bulgaria also conducted research in this field. Patonov, in his dissertation paper proves with calculations that, ,an increase in the portion of costs from the local government as part of the total share of consolidated budget costs contributes to the increase in the rate of annual increase of the Gross Domestic Product. According to the received empirical results, any increase in the amount of revenues from local government has a negative influence over the economic activity and economic growth ". This conclusion contradicts Rodriguez-Pose and Kroijer who speak of an inverse relation.

\section{MATERIALS AND METHODS}

This study defends the thesis that individual countries differ very much in their social economic state and for this reason should not be included into any panel studies /even if split into separate categories/. This circumstance is a result of the following expert evaluation. Following the changes in 1990, the countries in Europe were divided into 4 provisional groups: First group of countries - „Engines“Germany, France, Denmark, Netherlands, Belgium, Italy and etc.;

Second group of countries - „Condensers“Spain, Portugal, Greece and etc. These countries for decades occupy leading economical positions in Europe as a result of their conducted supranational policies. However, they all have a common problem. The economic potential they have accumulated as a result of many endeavors could disappear in a blink and the remaining vestiges are inherent for the countries after the economic upheavals in the 30-ies of XX century. The Spanish economy is an illustration of this, which in the years of the economic crisis after 2009 reached levels of unemployment higher than $20 \%$. Thanks to its "condenser" effect, the countries in this group can again accumulate satisfactory economic potential even if this takes a longer period of time;
Third group of countries - „Sprinters“ Czech Republic, Lithuania, Latvia, Estonia, Slovenia and etc. - these countries introduce major reforms and as a result of these they manage to attract and win the confidence of foreign investors. The economies of these countries achieved extraordinary results in their development and this has been acknowledged by their admittance as full members of EU in 1995. The speed of growth has strategic importance for these countries;

Fourth group of countries - „Marathon runners"-Romania, Bulgaria, Serbia and etc. Here the speed of economic growth is irrelevant. There is a final goal set but the time and speed for its accomplishment is not clear. These countries are characterized with insufficient level of reforms and inefficient public sector and the foreign investors are not confident in the available opportunities for doing business. As a rule, these countries react with a certain delay to the international and regional economic processes /for example, to a crisis / and are strongly dependent on the export of their goods and services. By virtue of their economic position arise multiple social and demographic issues.

The purpose of this survey is to compare a country labeled as a „marathon runner“ with a country - ,sprinter“. To this end, Bulgaria was selected /as a representative of the last group/, the Czech Republic /as a representative of the successfully reformed countries after 1990 /and Estonia /as a representative of the countries with small population but offering a satisfactory package of public services/. The regression equation (1) used is a simple one:

$\Delta G=a+b L R+c L E(1)$

Whereas:

$\Delta \mathrm{G}$ - is the change in the GDP on annual basis in comparison to a previous period;

LR - is the local revenues, calculated as a portion of all public revenues;

LE - is the local costs, calculated as a portion of all public costs;

The output data cover the period from 2000 to 2014 and are taken from the informational database of Eurostat.

\section{RESULTS}

Table 1 gives information for the size and population of the analyzed countries:

Table 1. Overview of the analyzed countries

\begin{tabular}{|l|l|l|l|}
\hline \multicolumn{1}{|c|}{ State } & \multicolumn{1}{c|}{ Area } & \multicolumn{1}{c|}{$\begin{array}{c}\text { Population } \\
01.01 .2014\end{array}$} & \multicolumn{1}{c|}{ Government structure } \\
\hline Bulgaria (BG) & 110 thou. $\mathrm{Km}^{2}$ & $7,245,677$ & Central, Regional (none), Local \\
\hline Estonia (EE) & 45 thou. $\mathrm{Km}^{2}$ & $1,315,819$ & Central, Regional (none), Local \\
\hline Czech Republic (CZ) & 79 thou. $\mathrm{Km}^{2}$ & $10,512,419$ & Central, Regional (none), Local \\
\hline
\end{tabular}


Figure 1 visualizes the data connected with the growth of national economies measured against the annual economic growth rates.

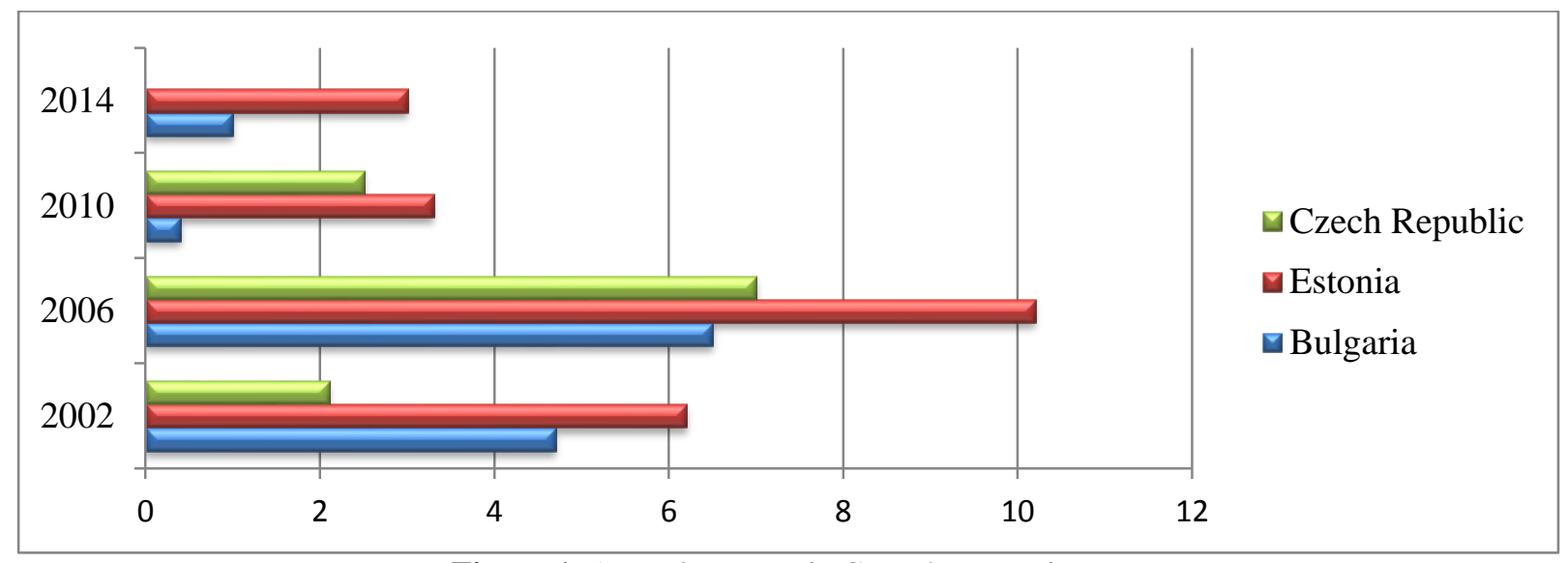

Figure 1. Annual Economic Growth Rate - in \%

Table 2 gives information about the scope of public costs on national and local levels:

Table 2. General and local public costs of Bulgaria, Estonia and Czech Republic for the period 2000 - 2014 /denominated in EUR/

\begin{tabular}{|c|c|c|c|c|c|c|c|c|c|c|c|c|}
\hline & \multicolumn{3}{|c|}{$\begin{array}{c}\text { Government revenue } \\
\text {-euro per inhabitant }\end{array}$} & \multicolumn{2}{|c|}{$\begin{array}{c}\text { Government } \\
\text { expenditure - euro } \\
\text { per inhabitant }\end{array}$} & \multicolumn{2}{|c|}{$\begin{array}{c}\text { Local revenue - euro } \\
\text { per inhabitant }\end{array}$} & \multicolumn{2}{|c|}{$\begin{array}{c}\text { Local expenditure - } \\
\text { euro per inhabitant }\end{array}$} \\
\cline { 2 - 14 } & BG & CZ & EE & BG & CZ & EE & BG & CZ & EE & BG & CZ & EE \\
\hline 2006 & 1269 & 4665 & 3652 & 1204 & 4938 & 3358 & 229 & 1297 & 907 & 222 & 1330 & 924 \\
\hline 2010 & 1691 & 5762 & 4488 & 1851 & 6422 & 4468 & 361 & 1628 & 1105 & 362 & 1687 & 1080 \\
\hline 2014 & 2110 & 5905 & 5843 & 2275 & 6197 & 5751 & 519 & 1511 & 1381 & 514 & 1487 & 1384 \\
\hline
\end{tabular}

Data from econometric processing are given in

Table 3.

Table 3. Results from processing of input data

\begin{tabular}{|c|c|c|c|c|c|c|c|}
\hline & $\mathrm{R}$ & $\mathrm{R}^{2}$ & Constant & LR & LE & Sig & Durbin-Watson \\
\hline Bulgaria & 0.682 & 0.465 & 19.710 & -0.920 & 0.055 & 0.023 & 1.990 \\
\hline Estonia & 0.639 & 0.408 & 32.394 & -4.478 & 3.187 & 0.043 & 2.158 \\
\hline Czech Republic & 0.440 & 0.193 & -8.934 & -1.405 & 1.961 & 0.275 & 1.034 \\
\hline
\end{tabular}

\section{CONCLUSIONS}

The conclusions could be grouped into several directions:

$>$ Credibility of analysis and achieved results - the use of panel data for measuring the connection between financial decentralization and economic growth requires extra attention. This is due to the fact that every country has specific characteristics and their consolidation /even in separate groups/ could incline the measured dependencies in any given direction.
When comparing the countries, that are the object of this study, we can make several econometric conclusions: 1 . The approved econometric model has low level of relevance for the Czech republic. That is why, the Czech Republic was excluded from the comparative analysis which was focused onto Bulgaria and Estonia; 2. Remaining two countries show similar

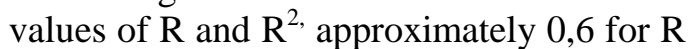
and 0,4 for $R^{2}$ respectively i.e. the evident, considerable correlation /between 0,5 and $0,7 /$ between dependent and independent variables is visible for only $40 \%$ of the 
cases. This is easily explained with the fact that the equation does not include independent values that have a proven influence over the economic growth - such as capital, investments etc. and the attention is focused only at certain parts of public costs;

Regressive coefficients measuring the influence of local revenues for both countries are negative values, which mean that the processes of decentralization should be aimed at expanding and optimization of cost authorizations rather than transfer of revenue authorizations. This is especially valid for Estonia where there are big reserves with regard of transfer of cost authorizations that might have a positive effect over the economic growth while for Bulgaria - these reserves are more limited. Again this proves that the centralized governments are better administrators of state revenues, especially in case of direct income tax;

The goal of this study has been achieved and there was an attempt made to measure the connection between fiscal decentralization and economic growth for three countries, which have considerable differences in their social - economic growth.

\section{REFERENCES}

1. Davoodi, H. and Zou, H., Fiscal Decentralization and Economic Growth: A Cross-Country Study, Journal of urban economics, 244-257, 1998

2. Rodríguez-Pose, A. and Krøijer, A., Fiscal Decentralization and Economic Growth in Central and Eastern Europe, LSE 'Europe in Question' Discussion Paper Series, 2009

3. Patonov, N., Fiscal decentralization and economic growth of the countries of the European union, 2013

4. Xie, D., Zou H. and Davoodi, H., Fiscal Decentralization and Economic Growth in the United States, Journal of Urban Economics, 228-239, 1999

5. Zhang, $\mathrm{T}$ and Zou, H., Fiscal decentralization, public spending, and economic growth in China, Journal of Public Economics, 221-240, 1998 